\title{
Cross-Cultural Analysis: Representation of Some Aspects of a Parent-Child Relationship (on the Examples of English and Uzbek Proverbs)
}

\author{
Feruza Mamatova ${ }^{1 *}$ \\ ${ }^{1}$ JMCU, Foreign Languages Department, 89 Qiyot, Uzbekistan
}

\begin{abstract}
The research paper deals with the problems of modern linguistics such as linguistic picture of the world which is realized principally by researching culturally marked linguistic phenomenon. A parentchild relationship is mostly studied by sociology, however, the fact that variety of speech in a parent-child relationship which is reflected in a linguistic image of the world makes it an object for linguistics. In addition to this, the study of the reflection of family relationship in the language enables to carry out a cross-cultural analysis by tools of linguoculturology. As data of the research English and Uzbek proverbs were selected from different sources. Analysis of phraseological units of English and Uzbek proverbs related to a parent-child relationship enabled to reveal similarities, differences, unique and specific features of this type of tradition. The periphery of this phenomenon comprises such notions as "parents are irreplaceable people", "parents' love" and "child's behaviour at different ages", "child associations" and others. Proverbs create a clear imagination of a parent- child relationship that has enough connotations expressed in the language. The analysis of the research may be implemented in cross-cultural studies, translation lessons and can be useful for a further research in this area.
\end{abstract}

\section{Introduction}

Anthropocentrism enables to get acquainted with the culture of a certain ethnos through the language. It is claimed that interconnection of language and culture is a bridge between person's word outlooks, mentality, nationality, national peculiarities and a language, since all of them are reflected in the language a person speaks. As anthropocentric direction in linguistics has attracted the scientists' attention there have been done a great deal of investigations where culture and language are the principal subjects. Traditions being considered one of the essential part of the culture of any nation as a rule, are reflected in the language too. Family traditions are a considerable part of traditions and they are inherent to the cultures of English and Uzbek nations. The study results show that a parentchild relationship reflected in proverbs vividly express culture-specific features of English and Uzbek family traditions. In order to reveal similarities, differences and unique features of some family traditions reflected in the English and the Uzbek linguoculturology, we have addressed to the proverbs of these languages. This, it is hoped, would assist the reader in comprehending the application of proverbial peculiarities in English and Uzbek.

Under the concept of family traditions are not only celebrations, holidays and ceremonies, customs but they also include a traditional relationship passing from one generation into another. A person's relatives no matter whether close or distant they have a certain place in his/her life. Kinship according to its degree of closeness can be divided into blood relatives and inlaws. In this research we aimed to make a comparative analysis of relations among these types of relatives in the English and Uzbek languages. "Family, family bonds and kinship relations form a nation's culture and show its peculiarities and assist to realize widely the national, linguistic image of the world" [29]. As the issue of family relations touch not only sociological science but also, cultural and linguistic ones, it is natural to approach to this problem from the perspectives of linguoculturology. Linguistic units possessing cultural-national features attract researcher's attention due to their study of linguistic image of the world of a native speaker. Phraseological and paremiological units which embody nationalcultural worldview obtain the role of cultural stereotypes [25]. The research demands to clarify who exactly relate to the group of blood relatives. A Russian linguist, historian gives following classification of blood relatives:

1) Me and my siblings;

2) My father, my mother and their generation;

3) My grandparents and their generation;

4) My children; 5) my all grandchildren [24].

For children a family is one of the main habitats, development and psychological formation. It is family which creates relationship between family members. Parents are the principal sources of developing interpersonal relationship for their children (interrelation of parents and children, relationship of parents and ancestors). This issue has attracted the attention of a great number of scientists. So, what is a 
parent-children relationship? Relationship of parents and children is explained by Dunn\& Brown [7]. As they claim, this form of relationship enables a child to understand emotions, since in the conversation of parent and a child emotional speech is inevitable when a small child tells the parents various situations, cases with full of joy, surprise and other feelings. Another scientist claims that sincere conversation in the a parent- child relationship guarantees respect, trust and security in psychology of a child [3]. A number of studies are devoted especially to the importance of a parent-child communications in the family. Despite the parents' love they must promote their capabilities to communicate with children and to listen to them. Communication depends on two interlocutors and it must not be stopped in any case Hisham Altalib, AbdulHamid AbuSulayman, \& Omar Altalib [10]. The quality of relationship highly depends on a parentchild communication, parental feelings of aggravation Moore, Kristin \& Busby, Andrea \& Bandy, Tawana [23]. Another group of scholars support the idea that the earlier a parent-child relation is formed the more successful relationship is built up, since communication is associated with emotional survival, comprehension of emotions [8]. Parents vary, however, in the extent to which they discuss emotions with their children. Relative to insecure parents, secure parents may feel more comfortable engaging in discussions with their children about positive and negative emotions, and as a result, children of secure parents may have greater opportunities to discuss and think about emotions. Although most work on predictors of children's emotion understanding has focused on either parent characteristics, such as depression [25]. One longitudinal study provides evidence for a link between parents' attachment and children's emotion understanding [27]. English and Uzbek languages relate to different language families that makes the research not ordinary. Different cultures, mentality, life experience of these two nationalities are reflected in the language, specifically in proverbs. Contrastive and linguoculturological analysis of English and Uzbek proverbs about a parent-child relationship is new for linguistic research, since a close examinations are carried out to find out culturally specific aspects of the under study issue. There exist a variety of stereotypes about a parent-child relationship in the English and Uzbek nations. These stereotypes are reflected in the language, specifically in the proverbs, sayings and idioms. At this point it is logical to discuss the capability of proverbs as a linguistic phenomenon in revealing cultural features of a certain ethnos. To illustrate, Louis [17] argued that "proverbs are a kind of linguistic instrument, a rhetoric device by which people attempt to get other members of their culture and society to see the world and behave in a common way". According to Burger proverbs reveals the unchanging features of the mentality, as they live for many centuries and have a various frequency of use in the language [Burger]. Proverbs are representatives of such significant categories for national cultures as the style of life, traditions, customs, word outlook, character, habits and appearance [Jahr, Scwarz-Frisel].
Family relations are characterized by specific indication as love, help, and support in matters related to the social and physical needs of the family members. These features of family relations are rooted in the public consciousness and are reflected in such notions as "parents' love", "value of children". It is also necessary to point that family relations differ from other interpersonal relations, as they are subject to regulation by society, which gives the family relations an element of responsibility and duty. The experience of many generations and universal values, which are the basis of family relations, are reflected in numerous proverbs $[11,12,18]$. Russian linguist Vorkachov states that "a unit of knowledge and conscience shared by a large group of people who speak the same language, with a fixed linguistic form (expression), which is marked by distinct ethno cultural specifics" [32].

\section{Literature review}

In linguistics, the terms comparative and contrastive have come to mean two different approaches: the first one focuses on the similarities between two (or more) sets of the same class of items, while the contrastive is mainly concerned with explicating, studying, describing and explaining the differences between linguistic items on the synchronic plane. In paremiology however, these terms are often used as synonyms [22]. It should be noted that by comparative, i.e. diachronic research proper, both in linguistics and in proverb study, it is suggested to understand diachronic or historical study which takes into account the evolution of a text, or the chronological change of some aspects of a proverb text or group / class of proverbs.

Approaches to studying a parent-child relationship have been made from different perspectives such as psychiatry [6] and psychology [2]. This issue has attracted the attention of sociologists, psychologists, sociolinguists and linguists for many years. On the basis of literary texts, mass communication publications, poems Lavitskiy describes the concept "Children" of Vitebsk region in Belarus in his scientific article. He investigates children's life from different prospective of life in which the role and place of parents are inevitable. Go Pintin [28] approaches the issue as a family tradition and compares Chinese and Russian a parent-child relationship basing on the proverbs and sayings of the two languages. Biktagirova [4] carries out comparative analysis of the issue in the concept "Family" on the materials of systematically different languages as English, Turkish and Tatar languages. Adamova [1] investigates the issue in her research dedicated to interpersonal relationships of English and Lak (Northeast Caucasian language) languages. Another research studies the concepts "Mother, father and children" as the representation of the world of "one's" in the Kuban phraseology [5]. Studying a parent-child relationship in linguoculturology enables to get acquainted with a linguistic image of the world of a certain nation. 
Comparative-linguoculturological analysis of a parentchild was carried out by Gasanova \& Mayorova [9] who compared Lezgin languages - Agul, Rutul and Tsakhur using proverbs of this language as a tool of the research. Another lingucultural analysis by Gaychenya [14] was made on the basis of the concept "Family". Comparative method revealed culture specific features of Russian and Spanish a parent-child relationship.

\section{Methodology}

The research analysis started from description of a parent-child relationship in the English and Uzbek languages. Scientific articles, psychological, social science resources that exist in these languages, served to find the most reliable facts about different aspects of a parent-child relationship such as love, behavior, associations in the family, peculiarities of fatherchildren and mother-children relationships and others. The core of the study requires carrying out comparative analysis of English and Uzbek proverbs relevant for a parent-child relationship; therefore, the next step was to select them from proverb dictionaries. After selection, we tried to reveal similarities, dissimilarities, specific features and uniqueness of a parent-child relationship specific to the English and Uzbek family traditions. It is known that proverbs reflected in the language speak for the mentality, life experience, world outlook, culture of a certain nation. For that reason, comparative method of proverbs was carried out to find out linguoculturological peculiarities of a parent-child relationship reflected in the proverbs. Analysis of statistical method in linguistics provided with exact quantity of proverbs in the two languages that reveal this or that aspect of the research issue.

\subsection{Data collection.}

In order to collect as many proverbs as possible we addressed to a number of dictionaries in both languages [19, 20, 29, and 30]. More than 50 proverbs in English and 56 proverbs in Uzbek have been selected for further contrastive analysis.

\section{Results and Discussions}

The principal focus of the research was to analyse parent-child relationship proverbs within English and Uzbek society. To achieve this objective we picked English and Uzbek proverbs in which a variety of a parent-child relationship is revealed. Comparative analysis illustrate that there exist potential and important similarities and dissimilarities and specific features between English and Uzbek a parent-child relationship. The results of the research are provided in details in the tables. According to the study results, there were revealed proverbs about having a child in the family. Both Uzbek and English proverbs reflect the happiness of a child being in the family, besides we found an English proverb with the expression of disagreement and discomfort of parents in having a child as well (see table1).

Table 1. Proverbs that reflect parents' attitude to having children.

(The quantity of proverbs is engaged in figures)

\begin{tabular}{|c|c|c|c|c|}
\hline $\begin{array}{c}\text { Parent's } \\
\text { attitude } \\
\text { towards } \\
\text { having } \\
\text { children }\end{array}$ & $\begin{array}{c}\text { Pleased } \\
\text { with } \\
\text { having } \\
\text { children }\end{array}$ & $\begin{array}{c}\text { Desirable } \\
\text { amount of } \\
\text { children }\end{array}$ & $\begin{array}{c}\text { Desired } \\
\text { time of } \\
\text { having } \\
\text { childre } \\
\text { n }\end{array}$ & $\begin{array}{c}\text { Attitude } \\
\text { to the } \\
\text { absence } \\
\text { of } \\
\text { children }\end{array}$ \\
\hline English & 5 & 1 & 1 & 2 \\
\hline Uzbek & 6 & 1 & 1 & 12 \\
\hline
\end{tabular}

It can be seen from table 1 that both English and Uzbek are pleased to have children, almost the same number of proverbs about the joy, happiness of having children indicate that it is specific for both societies to show positive attitude towards children in the family. Here are examples: A babe in the house is a well spring of pleasure [19] or Uzbek proverb Odamning mevasi bola (A human's fruit is a child). The most distinctive aspect between English and Uzbek proverbs is the presence of some English proverbs expressing a merely positive attitude of having children and the absence of proverbs with such connotations, for instance: He that has a wife and children has given hostages to fortune or Children certain cares, but uncertain comforts. Another evident difference is reflected in the amount of proverbs expressing the matter of absence of children in the family, 1 proverb in English (The house without children is cemetery) and 12 proverbs in Uzbek, the reason for this can be explained that Uzbek society is considered to be a child-loving nation (Болали уй жаннат-боласиз уй миннат; Болали уй бозор, боласиз уй мозор [29] and others). In the section of table 1 the amount of proverbs concerning the issue of desirable amount of children is the same in both languages. However, they contradict in the meaning, whereas Englishmen believe that a lot of children require a lot of effort whereas the Uzbek people consider that every child in the family no matter how many they has his/her own place in the heart of the parents: Eng. Many children, many cares, no children, no felicity and Uzb: Ўнта бўлса ўрни бошқа, қирқта бўлса қилиғи бошқа. The same case was revealed in the section which illustrates the desired time of having a child. While some English proverbs advise to start a family as soon as possible, since a big difference between the age of parents and children may negatively impact on child's destiny: Late children, early orphans, it is not troublesome issue for Uzbek when to have children, any time suits them: Фарзанд билан давлатнинг эрта-кечи йўк (There is no time limited to have a child and to be rich).

Table 2 mentions the presence of the love in a parent-child relationship. Comparison of parent's love in the proverbs showed not a considerable difference in two languages, Uzbek proverbs about father's love is slightly more than in English, the similar amount about mother's love proverbs may be seen. 
Table 2. Love and affection in a parent-child relationship (The quantity of proverbs is engaged in figures)

\begin{tabular}{|l|c|c|c|c|}
\hline & $\begin{array}{c}\text { Comparing } \\
\text { father's } \\
\text { and } \\
\text { mother's } \\
\text { love }\end{array}$ & $\begin{array}{c}\text { Father's } \\
\text { love }\end{array}$ & $\begin{array}{c}\text { Mother } \\
\text { 's love }\end{array}$ & $\begin{array}{c}\text { Childre } \\
\text { n's love }\end{array}$ \\
\hline Eng. & 1 & 1 & 1 & 1 \\
\hline Uzb. & 3 & 4 & 1 & NA \\
\hline
\end{tabular}

In Table 2 we found one English proverb about children's love (The best love is that of children); however we did not come across any Uzbek proverbs expressing a child's love. In the process of investigation of parent- child proverbs, we revealed a number of proverbs which denote metaphorical meaning of richness, welfare in different images of parents if they possess children. For English, two proverbs out of three that we found express the state of richness of having children is close to the image of poor parents and one for all parents, whereas in Uzbek proverbs children are richness for every parent despite their status of being rich or poor. For example, Children are the parents' riches, Children are poor men's riches, Uzbek proverbs: Давлатнинг боши фарзанд (The beginningof richness is children), Давлатинг - ўғил- қизинг (Daughters and sons are your richness). See table 3:

Table 3. Children are parents' richness (the quantity of proverbs is engaged in figures)

\begin{tabular}{|l|l|l|l|}
\hline $\begin{array}{l}\text { Social } \\
\text { classes } \\
\text { parents } \\
\text { belong }\end{array}$ & $\begin{array}{l}\text { Poor } \\
\text { parents }\end{array}$ & Rich parents & Both \\
\hline English & 1 & 1 & 1 \\
\hline Uzbek & NA & NA & 3 \\
\hline
\end{tabular}

Analysis of table 4, which is about what parents associate children with, showed that children are assimilated only with positive things in both linguoculturology. Examination of this aspect of a parent-child relationship revealed several similarities as well as differences and uniqueness. Similarities were found in associations of children with sweets, sweet food in the English and Uzbek languages. For example, Children are the sweetest things of all to own, in the Uzbek proverbs children are associated with honey, sweets, e.g: Фарзандим - асал-қандим (My children are my honey and sweets). The statistics in figures is illustrated in the following table:

Table 4. The things children are associated with (The quantity of proverbs is engaged in figures)

\begin{tabular}{|c|c|c|}
\hline Associations & Eng. & Uzb. \\
\hline Sweets & 1 & 2 \\
\hline Paradise & 1 & NA \\
\hline Parts of body & NA & 2 \\
\hline Nature & NA & 1 \\
\hline Heaven & 1 & NA \\
\hline Pleasure & 1 & NA \\
\hline Power & NA & 1 \\
\hline
\end{tabular}

As can be seen from the table 4 , associations in the languages differ considerably, $90 \%$ of associations are dissimilar. This is explained by the life style, mentality, values, culture of each nation. To illustrate, for Uzbek children are future assistants in the household chores when they live together a strength that motivates parents to live, work and generally exist in this live, besides this, no Uzbek family can imagine his/her life wothout children, therefore, children for Uzbeks are associated with a human's eyes: Фарзанд - дилбанд, фарзанд- қанот (Child is a soul mate, child is a wing); Ўғил билан қизинг - мисоли икки кўзинг (Your son and daughter are your two eyes); Куч билан фарзанд - белнинг куввати (Power and child is strength for body). As for English, children are pure, naïve, clean beings, so the proverb where children are not heaven is not reflects peace, clearness that a child has.

Considering table 5, that illustrates English and Uzbek proverbs about parents' not objective attitude to their children, it was revealed that every that illustrates English and Uzbek proverbs about parents' not objective attitude to their children, it was revealed that every parent stand up for their children, protect them being sure that their child is the most and the best of all, this case cannot be a culture specific, it is mostly a social phenomenon. In this state, Uzbek and English proverbs have exactly the same connotations in proverbs, as well as equalize in quantities. The followings can be proof for above mentioned facts: He, whose father is judge, goes safe to trial; the crow thinks her own bird fairest and Uzbek proverbs Кўнғиз боласини оппоғим дер, типратикан боласини юмшоғим дер (The beat says that his own insect's body is white and a hedgehog says that his child is soft). Concerning how children's treat their parents depends at the age they are the moment of the relationship. Here, we revealed that English proverbs determine that attitude of children change as they grow up, the changes happen from minor to major, from physical to psychological that may cause serious, social, psychological damage to parents whereas children at early ages, according to English, can bring only mere physical and emotional difficulties which are considered only joy and happiness for parents, for instance Little children, little sorrows; Children suck their mother when they are young, and the father when they are old; Children when they are little make parents fools, when they are great they make them mad. For Uzbek, proverbs demonstrate that changes in children's behaviour has a physical aspect, the older the child gets the more parents get tired of taking care their children, for instance: Бола югурса кексанинг оёғи зирқирар (When child starts going, it makes an old parent's leg ache). The detailed data is given in the table below:

Table 5. Parents' subjective attitude towards their own children and age based a parent-child relationship (the quantity of proverbs is engaged in figures)

\begin{tabular}{|c|c|c|}
\hline $\begin{array}{c}\text { Parent-child } \\
\text { interrelation }\end{array}$ & English & Uzbek \\
\hline $\begin{array}{c}\text { Parental } \\
\text { subjective } \\
\text { attitude }\end{array}$ & 7 & 6 \\
\hline
\end{tabular}


Changing features of children's behavior based on age

\begin{tabular}{|c|c|c|c|}
\hline & Physical & Psychological & Financial \\
\hline English & 4 & 3 & 1 \\
\hline Uzbek & 3 & NA & NA \\
\hline
\end{tabular}

\section{Conclusion}

According to Ghazala proverbs are "special, fixed, unchanged phrases which have special, fixed, unchanged meanings" [12]. Meider claims that and their traditional function is didactic as they contain "wisdom, truth, morals and traditional views"[16]. The principal focus of the research was to carry out analysis the English and Uzbek a parent-child relationship in the frame of paremiological fund of the two languages. In order to reveal any potential considerable similarities and dissimilarities between English and Uzbek a parent-child relationship, proverbs selection and comparative-linguculturological method was used. Data analysis found out that there exist significant differences in the consideration of:

(1) Attitude towards having children

(2) Love and affection in the relationship

(3) What parents associate children with (4) Belief that children are parents' wealth changes in the child's behaviour based on his/her age.

The research of our data has illustrated that a parent-child relationship is culture specific and is reflected in the linguistic picture of the world mostly by means of proverbs. Dealing with the different types of a parent- child relationship within English and Uzbek cultures showed that cultural factors play an important role in this issue. The research of our data has illustrated that a parent-child relationship is culture specific and is reflected in the linguistic picture of the world mostly by means of proverbs. Dealing with the different types of a parent- child relationship within English and Uzbek cultures showed that cultural factors play an important role in this issue.

\section{References}

1. Adamova S.M. Poslovitsi I pogorki otrajayushiye mejlichnostniye otnosheniya v yazykah razlichnyh kultue: Lakskom i angliyskom [Proverbs and sayings reflecting interpersonal relationship iin the languages of different culture: Lak and English] Extended Abstract of Candidate Dissertation, Makhachkala, "Firma KIT" IP Dagermanov I.D. (2015).

2. Bagga I., Saini S. An analysis of a parent-child relationship as perceived by adolescents. Adv. Res. J.Soc. Sci., 8 (2): 188-193, (2017). https://doi.10.15740/HAS/ARJSS/8.2/188-193.

3. Bretherton, I. Communication patterns, internal working models, and the intergenerational transmission of attachment relationships. IMHJ,11(3), 237-252, (1990).

4. Biktagirova Z.A. Kontsept "Semya" v paremiologii angliyskogo, turetskogo i tatarskogo yazykov [Concept "Family" in the paremiology of English, Turkish and Tatar kanguages] Extended Abstract of Candidate Dissertation, Kazan, Mnojitelniys tsentr Instituta istorii AN RT Publ., (2007).

5. Burdun S.V. Kontsepti mat',otets, deti kak reprezentanty mira "Svoih" (na materiale kubanskoy frazeologii) [Consepts mother, father, children as representatives of the world "One's" (on the materials of Kuban phraseology) $\mathrm{PhN}$. 13(4), (2020). https://doi.org/10.30853/filnauki.2020.4.2

6. Chen Q., Du, W., Gao Y., Ma Ch. Analysis of Family Functioning and A parent-child Relationship between Adolescents with Depression and their Parents. Shanghai Arch Psychiatry, 29(6). 365-372, (2017). 10.11919/j.issn.10020829.217067

7. Dunn J., Brown J. Affect expression in the family, children's understanding of emotions, and their interactions with others. Merrill Palmer Q. 1994; 40:120-137. [Google Scholar]

8. Dunn, J., Brown, J., Slomkowski, C., Tesla, C., \& Youngblade, L. Young children understand of other people's feelings and beliefs: Individual differences and their antecedents. Child Dev, 62, 1352-1366, (1991).

9. Gasanova M.A., Mayorova G.V. Lingvokulturologicheskiy analiz kontsepta "Rebyonok" v poslovisah I pogovorkah agulskogo, tsahurskogo i rutulskogo yazykov [Linguoculturological analysis of the concept "Child" in proverbs and sayings of Agul, Rutul and Tsakhur languages, USN, vol. 8, (2016).

10. Hisam A., AbdulHamid AbuSulayman, \& Omar Altalib, A parent-child Relations: A Guide to Raising Children, 528-529, (2012).

11. Herbrand, F. Intercultural competence. Competitive advantage in a globalizing economy. Bern, Stuttgart, Vienna: Verlag Haupt (2010).

12. Hofstede, G. Local thinking, global action. Berlin: German paperback publishing house, (2010).

13. Jahr, S. Feelings and Emotions structures in expository texts. Berlin: Walter de Gruyter, (2000).

14. Gaychenya A.A. Kontsept "Semya" v russkoy I ispanskoy yazykovih kartinah mira.

Lingvokulturologicheskiy analiz [Family concept in Russian and Spanish language pictures of the world. Linguo-cultural analysis] Language and Text langpsy.ru 2018, vol. 5, no 4, 68-77, (2018).

15. Ghazala, H. Translation As Problems and Solutions: A Coursebook for University Students and Trainee Translators. Beirut: Dar waMaktabat Al-Hilal, p.138, (1995). 
16. Laible, D. J., Thompson, R. A. Mother-child discourse, attachment security, shared positive affect, and early conscience development. Child Dev, 71, 1424-1440, (2000).

17. Louis, C. Proverbs and the Politics of Language. Proverbium 17: p. 172-194. Yearbook of International Proverbs Scholarship. The University of Vermont (2000).

18. Maletzke, G. Intercultural Communication. For interaction between people of different cultures. Opladen: West German publishing house, (2013)

19. Manser M. The Facts on File Dictionary of Proverbs, New York, InfoBase Publishing, p 185, (2007).

20. Margulis M., Kholodnaya A. Russko-Angliyskiy Slovar Poslovits i Pogovorok [Russian- English dictionary of Proverbs and Sayings], McFarland \& Company, Inc., Publishers Jefferson, North Carolina, and London, p.26-39, (1974).

21. Mieder, W. Proverbs: A Handbook. USA: Greenwood Press, p 3, (2004).

22. Mieder, W. \& Dundes, A. Preface. In W. Mieder $\&$ A. Dundes (Eds.), The Wisdom of Many. Essays on the Proverb. 2nd ed. (pp. vii-xiii). New York: Garland Publishers, (1994).

23. Moore K., Busby A., Tawana B. Parental relationship quality and child outcomes across subgroups, Child Dev, 13, (2011).

24. Olderogge V.A. Malayskaya sistema rodstva//Rodovoe obshestvo. Materialı İssledovaniya. M., (1951).

25. Raikes, H. \& Thompson, Ross. Family emotional climate, attachment security and young children's emotion knowledge in a high risk sample. Br J Dev Psychol, 24 (89), (2006)https://doi.org/10.1348/026151005X7042.

26. Schwarz-Friesel, M. Language, Cognition and Emotion: New Directions in Cognitive Science. In M. Schwarz-Friesel. Language-cognition-culture, pp. 277-301.Stuttgart: UTB, (2007).

27. Steele, M., Steele, H., Johansson, M. Maternal predictors of children's social cognition: An attachment perspective. J Child Psychol Psychiatry, 43(7), 861-872, (2002).

28. Pintin G. Reprezentatsiya semeynih traditsiy $v$ russkoy i kitayskiy yazikov kartinah mira [Representation of family tradition of Chinese and Russian in the linguistic pictures of the world]. Extended Abstract of Candidate Dissertation, Ufa, Redaktsionno-izdatelskiy sentr Publ., (2018.

29. Salimova L.M. K voprosu ob izuchenii russkoy yazikovoy kartiny mira (po "Besedam o russkoy kulture" Yu.M.Lotmana. Filologicheskiye nauki. Voprosi teorii i praktiki, 1(31), (2014).

30. Shomaqsudov Sh., Shorahmedov Sh. Ma'nolar mahzani [Treasure of meanings] Tashkent, Ozbekiston Milliy Ensiklopediyasi, pp 167-428, (2009).
31. Speake J. The Oxford Dictionary of Proverbs: New York, Oxford University Press, p 536-539, (2008).

32. Telia V.N. Russkaya frazeologiya: Semanticheskiy, pragmaticheskiy $i$ lingvokulturologicheskiy aspekti. M.: Shkola "Yaziki russkoy kultury", 288-289, (1996).

33. Vorkachov, S. G. Lingvoconceptology and crosscultural communication:sources and aims Philologicheskiye nauki, pp.76-83,(2005). 